\title{
WHEN A WOMAN IS MOTHER: FEMININE JOUISSANCE IN MOTHERHOOD
}

Márcia Barcellos Alves and Maria Cristina Poli

Márcia Barcellos Alves

Universidade Federal do Rio de Janeiro (UFRJ),

Programa de Pós-Graduação em Teoria Psicanalítica, Rio de Janeiro/RJ, Brasil.

Maria Cristina Poli Universidade Federal do Rio de Janeiro (UFRJ), Programa de Pós-Graduação em Teoria Psicanalítica, Rio de Janeiro/RJ, Brasil.
ABSTRACT: From the clinical listening of women concerning the strains of motherhood, this article intends to discuss the indications of Sigmund Freud and Jacques Lacan regarding the comings and goings of the feminine and the maternal positions. This article proposes that Lacan's writings on the matter of jouissance make it possible to discuss the relation between feminine and maternal through a path other than that of complementarity but neither one of exclusion, insofar as that relation may be taken within the condition of supplementarity.

Keywords: psychoanalysis; femininity; feminine; maternal; jouissance.

RESUMO: Quando uma mulher é mãe: o gozo feminino na maternidade. A partir da escuta clínica de mulheres acerca dos impasses da maternidade, este artigo pretende problematizar as indicações de Sigmund Freud e Jacques Lacan com relação aos encontros e desencontros das posições feminina e materna. Este artigo propõe que o trabalho de Lacan sobre o campo do gozo torna possível problematizar a relação entre o feminino e o materno por uma via que não seja a da complementaridade ou tampouco a da exclusão, na medida em que tal relação possa ser tomada na condição de suplementaridade.

Palavras-chave: psicanálise; feminilidade; feminino; materno; gozo.

DOI - http://dx.doi.org/10.1590/S1516-14982016002003 
$\mathrm{T}$ he matter which drives this article starts with the conjunction of interrogations arising from the psychoanalytical clinical experience with some propositions within the field of Freudian and Lacanian formulations. Its base, therefore, lies in the moebian relation between clinic and theory, to the point where one cannot tell which of the two spheres has precedence or prominence in the capacity of interrogation, which is, insofar, mutual.

Amidst not so consensual theoretical debates and the clinical listening of women, both concerning the dilemmas aroused by the decision to experience being a mother and also concerning the relation between what is, within the psychoanalytical theory, designated as being a mother and what is designated as being a woman, resurfaces posing a question. Beyond the singularity of each case, both in terms of the repetition of some of these conflicts and the entanglement that these interrogations seem to admit with culture and with psychoanalysis itself, a vast field of research was revealed through those pathways.

Some clinical passages, as the ones cited below, set the tone of this article and illustrate the referred moebian condition of the relation between clinic and theory, while also demonstrating matters referring to the contours that the debate "mother versus woman" assumes at the present time. As indicated by Freud at different moments (1921, 1930 [1929]), individual and social are spheres that interpose and engender each other mutually. Psychoanalysis has witnessed, for over a century, that the transformations in clinical manifestations follow the echoes of a certain time and culture.

Under that premiss, we offer some clinical fragments as a way to interrogate Contemporaneity concerning women's relationship with motherhood':

"There is so much that comes before the moment to have a child that I think that when that moment does come, I'll be too old. I have my master's degree to finish and I really want to pursue my doctor's. I hope that after that I'll have good financial conditions, something that worries me too. I even have to, you see, find someone who wants to be a father, a father to that child of mine". (Patient A)

"I'm terrified. I don't know what to do with the little thing. Some things I looked up on the internet, but not even Google can help me, every website says something different". (Patient B)

Because the possibilities for phallic realization for women have been expanding, past the field of motherhood, debate has been further magnified around the bond between the positions of a mother and a woman. Professional activities, financial responsibility, changes in social status and acknowledgement of homo 
or heterosexual relationships are examples of the diversity that such phallic realizations have been acquiring.

Next, we will approach Lacan's considerations within the field of jouissance to discuss the aforementioned bond between mother and woman. While Freud's comprehension is that motherhood is a phallic way out for the feminine Oedipus, and Lacan's stand is that the feminine jouissance is in a relation of supplementarity with the phallic jouissance, a pathway of significant questions is set, regarding the distance and the encounter of the maternal with the feminine, as attempted to demonstrate as follows.

\section{THE FIELD OF JOUISSANCE}

Lacan's considerations in the field of jouissance reached further theoretical development and problematization in his latter Seminars. That is also, not by chance, the moment when Lacan dedicates himself more directly to the matter of the feminine, regarding the order of the Real, which offers clues on the "web" of conceptual elements where he develops both matters.

In Seminar XX, Encore (1973[1972/1985), Lacan points out that jouissance refers to that which the subject doesn't want to know about, even if talking about it incessantly. The starting point on the matter of jouissance that Lacan worked on is Freud's formulations on the concept of pulsion and, more specifically, what he describes as repetition in Beyond the Pleasure Principle (1920/1996). Jouissance concerns a repetition that the establishment of the pulsional circuit instates, distinguished for not having any use, and still, pressing. That repetition is not considered natural, it doesn't function as biological automation: it is the subject's harnessing of the language that establishes it, because even though jouissance escapes it, it is in the repetition of the signifying chain that it pulsates.

Lacan proposes that the devices of jouissance are meant to approach reality. The psychoanalyst (Lacan, 1973[1972]/1985) underlines that when it comes to devices, there is no other but language. It is through that device that jouissance is harnessed in the speaking being. If the unconscious is structured as language, that language is clarified when set as a device of jouissance.

Psychoanalytical literature is controversial when it comes to the matter of jouissance, often using several expressions that Lacan (1973[1972]/1985) proposes in opposing ways. Although he did not systematize the difference between each one, Lacan dedicates special attention to phallic jouissance and the Other's jouissance.

The Other's jouissance is described by some authors (such as Jerusalinsky, 2009) as an originary jouissance, a mythical one. As "the lost paradise" it can only be accounted for considering the phallic jouissance, retroactively, prior to it. 
Several authors involved with this theme propose a difference, one that is not directly appointed by Lacan, between the Other's Jouissance and the Other Jouissance. The first being within the phallic, would refer to the time when the baby was the receiver of the mother's jouissance, which would make up for her lack. The second is, then, taken as the feminine jouissance, beyond the phallic, supplementary to it (as will be elaborated further ahead).

Although this article considers the arguments regarding the difference proposed by those authors, it will follow Lacan's indication, which points toward the Other's Jouissance as the feminine one and does not regard the "category" of the Other Jouissance (in consonance with authors as Harari, 2006; André, 2011). The Other's jouissance is one of the body, also called by Lacan (1973[1972]/1985) the jouissance of the living or the jouissance of the being.

As the feminine jouissance, the Other's jouissance is beyond the phallic. The jouissance within the phallic is one that is not the Other's or the baby's, or that belongs to both, due to the indistinguishable nature that marks this initial relationship between mother and infant. In this sense, the idea is that the Other's Jouissance, the feminine one, would already bear the notion of a maternal jouissance (and not the mother's), since it is precisely a certain type of encounter between the feminine and the maternal that this article intends to contemplate, even if it is not the same as proposed by Freud, as will be evidenced.

The phallic jouissance, on the other hand, limits the jouissance produced during this time when mother and baby are confused with one another, once the paternal metaphor is established, which has the potency to interdict this primal relationship. It is the jouissance with language the one that is introduced with the signification of the phallus in the Oedipus Complex. Bound to the signifier, it is the jouissance of the speaking being, where the intermediation of the phallic function engages articulations and signifying substitutions, because it founds a symbolic debt and a desiring movement guided by the phallic search. Soler (2013) points out that the phallic jouissance, also called the One's jouissance, is located, limited and outside the body. It has lack-of-jouissance (manque-à-jouir) as correlational and it launches the superegoic imperative of jouissance (which guilt feeds on).

Apart from those considerations, Julieta Jerusalinsky (2009) underlines that the baby offers itself as object a to the Other who supposedly causes jouissance, complementing it. As an object, the subject produces an imaginary setup of an absolute Other. Imaginarily, for the subject, he himself is the object that fills the Other's lack, making him complete (realization of the image of the ideal ego [Ideal Ich]), whereas the phallic jouissance implies a symbolic identification as the ego ideal (Ich-ideal). 
The child's body serves the mother's jouissance. The smaller the child is, the more exposed it is to such passiveness. The clinical work with children is revealing in that sense: commonly, the claims of mothers who seek treatment for their children denounce the moments when the child ceases to submit itself to thatjouissance, which sometimes happensquite precociously, and sometimes, drags on through adolescence or even adulthood.

Regardless, the first object that one supposes adequate to the maternal demand (to the Other's desire articulated as a demand) is one's self, it is the ideal ego in Freudian terms, the I in the condition of maternal object. However, if that image is somehow realized, the price is falling into subjective aphanisis (fading), eclipsing one's own desire. Even though such risk is present, this time of primordial passiveness is central in the subject's psychic constitution. The condition for being the object for the Other's jouissance only assumes sexual signification with the intervention of the phallic signifier, a posteriori. The dialectics between passiveness and activity equals the oscillation between being the mother's object and taking the mother as object. When the child, boy or girl, takes the mother as object, the primacy of the phallus begins, as described by Freud in The Infantile Genital Organisation (1923/1996).

Thus, it is fundamental to stress that contemplating the relation between feminine jouissance and motherhood does not start with the exclusion of a phallic jouissance in the dynamics of motherhood, which would sustain devastating effects. Even though, as indicated by Sigal (2003) "a child is more than just a phallic shine to the woman", it is first necessary that the child be it. When a child is the mother's phallic shine, he/she starts earning the possibility of being something more than that. Within the phallic, there is only devastation. Beyond it, it is proposed that there may be creation. The need for a phallic statute is what brings this thesis and Freud's formulations on femininity together. It is Lacan, however, who offers conceptual consistency to this debate.

It is Lacan himself (1960/1998), in Guiding Remarks for a Convention on Feminine Sexuality, who adverts about that problematic: "it is suitable to question whether phallic mediation drains all that can be manifested as pulsion in a woman, noticeably the whole chain of maternal instinct" (p. 739). Seemingly, Lacan indicates, at that point, a possibility for a "mediation" beyond the phallic, of a pulsional way out that is other, present in motherhood, which is precisely the drive for this article.

The inclusion of the female jouissance as a supplementary one over the phallic indicates the Lacanian proposal for support of the phallus as an ordaining signifier in the symbolic chain, since it is the only one capable of stating a sexual difference for both genders, while it also signals a possible addition that the woman's side enables for only being included as not-whole in the phallic order. 
For a mother to also be a woman includes a possibility that the reference to the phallic order be present in a not-whole manner in her relationship with the baby. In the clinical work, the confluence of feminine and maternal often shows conflictual:

"I spent a good period of my pregnancy without medical clearance to have sexual relations. Now that the baby is here, I don't even have time to think about that. I admit that I don't feel like it, but I worry about my husband: will he withstand it?" (Patient C)

"I rented a two-bedroom apartment because we thought about having a baby right after the wedding. And the spare room has long been an office". (Patient D)

Both Freud and Lacan mentioned a woman's desire for a man as the main element that would diverge the mother's desire, which still seems to hold true in the clinical listening. In contemporaneity, however, it is far from being the only element that does that job, as revealed by both the introductory passages as the one mentioned above. The role that professional activities have started to play forwomen does not only postpone motherhood, as exemplified by the passages, but also has important consequences when a woman does become a mother.

"I don't like that nanny. She's not reliable. But I had an important meeting, so I had to call her". (Patient B)

Soler (2013) takes the matter from another standpoint and underlines the hiatus that exists between mother and woman, as only in some cases does the child, situated as the phallus, silence the feminine demand intensely. In those cases, motherhood ends up radically modifying the erotic position of the woman who is a mother. Nevertheless, the author stresses that hardly ever do the child's attributes seal the matter of desire.

That finding is welcome for the necessary operation of separation between mother and her infant, and there, it is not the mother's love that serves as a mediator, but its division by an object that is cause of her desire. That is why Lacan underlines the idea that the lack of an object and the importance of the child encountering a desiring mother (woman), a mother whose lack-of-phallus causes desire, beyond the "fulfilling" or "fulfilled" mother.

That is when Soler (2013) finds what, to her, constitutes the difference between being a mother and being a woman. That is, even if both refer to the phallic lack, castration, they are not in the same manner. According to the author, the mother resolves her lack by having, in the shape of a child, a substi- 
tute for the phallic object that she lacks. The author points out, however, that a woman's being a mother is not completely resolved in the substitutive phallus: as the woman also diverges her desire toward a man (a male of a female partner, we would add), that partner also incarnates the phallus to which the woman would aspire. Even down that path, she still needs to confront herself with the fact that something is missing.

J.Jerusalinsky (2009) also deals with those matters and shequestions whether the feminine jouissance only functions to limit the mother's phallic jouissance with the child, as a demand that she is also a woman. The mother, as a woman, experiences the jouissance of being masked as the object of the Other's desire. The mother, also as a woman, offers her body as a receptacle for the partner's phantom. As a mother, she raises a baby that does not present itself only as a phallic substitute, butemerges through the small objects that are set in scene: the look, the voice, the feces, the milk, the skin, the smell and other pieces present in the exercise of motherhood.

Besides,

That the mother, countless times, prioritizes the care of the child over her own is far from being and effect of a natural order, of the instinctive. It doesn't happen out of abnegation either, given that the economy of jouissance is never uninterested. It consists of an economy of jouissance that may be established, or not, in the mother-child bond. Far from being submitted to maternal masochism, it can be properly articulated with the repetition through which the mother accesses, herself, an Other jouissance - by enabling and attributing her baby with the enjoyment of life without having him need to occupy himself with the economy of jouissance. That is when the Other jouissance makes its appearance in motherhood, and not only opposing that exercise (JERUSALINSKY, 2009, p. 181).

Taking those matters into consideration, Soler's (2013) questionings are included, concerning what might be the repercussion on the child of that which is realized in the woman at the margin of phallic inscription. The especifically feminine desire would make the mother absent to the child: necessary absence, to be symbolized, it is absence that unveils the separation dialectics. The author underlines that the not-whole quietly attends the margins of what is put in order in the phallic series, which is driven in signs and institutes and orders that makes it possible for the child to position itself before desire, even if at a loss value.

Thus, Soler (2014) situates at one end of maternal harmfulness the mother that occupies herself totally with her child. At the other end, the author places the mother that is not involved with that task at all. The array of images of a mother thus unfolds to both extremes: the mother that is excessive, illustrated 
with the octopus-mother image, whose tentacles close in upon the child, and that woman who is "too much of a woman", that is such an Other that makes it impossible for someone to recognize oneself in her. From one end to the other, a range of possibilities... "whether it is more about one's body or more about one's being a subject and whether it is a boy or a girl, that changes a lot".

The clinical listening witnesses how much that array may reveal more and more inter-positions in the space between ends. What seems to recur, however, is the ever somewhat conflictual nature of the relation between the woman and the mother in her.

\section{FROM FEMININITY TO FEMININE: THE FIELD RELATIVE TO WOMEN}

The matter of confluence of feminine jouissance and phallic jouissance in women's relation with motherhood shows, as said, a vast field for debate. For these matters to be later resumed, a brief recap is recommended on how Sigmund Freud and Jacques Lacan, respectively, presented the theme of femininity.

Situating the differences between femininity and feminine implies, at first, warningthatthedebatebetweenthoseconstructions doesnotadmitpropositions based on a linear and descriptive comparability. The exercise of debating this or that perspective takes into consideration the fact that both have at least one trait in common: the field relative to women. Even though that which deserves to be called a woman in Lacan's writings is very much unlike the "Freudian woman", working with this and that perspective outlines a field for debate that reveals noteworthy issues, as will be examined.

Those matters get even more complex as Freud himself states that "in conformity with its peculiar nature, psychoanalysis does not try to describe what a woman is - that would be a task it could scarcely perform"(1933[1932]/1996, p. 117). To Freud, it's about inquiring how a woman comes into being, how she develops, especially with her bisexual nature.

Hence, Freud stays within the question "what is a woman?". In very general lines, in 1905 he suggests that "masculine" and "feminine" may be conceived in three different senses: they are, firstly, synonyms of activity and passivity respectively; secondly, they correspond to the presence of certain biological attributes that produce spermatozoa or ova; and in a third sense, they are sociological concepts, formed by the observation of different behaviors.

Freud (1905/1996) notes that, because of the relativity of the latter two, the psychoanalyst is interested in the first difference. The broad debate around the bisexual constitution of humans, however, makes the definition "masculine = active" and "feminine = passive" too complex to be summarized in those terms. What becomes clear in his works is the detachment from both the anatomical 
and the behavioral references, which were the "ways out" that up until that point offered a definition for what is a man and what is a woman.

On those matters, André (2011) highlights that, once without the anatomical reference, we do not know what embroils the terms "masculine" and "feminine", it is the activity-passivity opposition that sets the place for a viable relation between both terms, which is what the notion of "bisexuality" attempts to indicate. However, that perspective doesn't do more than generate prejudice, in the author's opinion: women would have a natural tendency to passivity, while men would have the same natural tendency to activity. That path, according to André (2011), is exactly the opposite of the idea indicated in the Freudian trajectory, that is, showing that there is no masculine of feminine nature.

Thus, besides the lack of an answer to what Freud calls a woman, in his work there is more than one version of femininity, as was noted by Poli (2007). Those versions are the result of the privilege that Freud assigns to the matter of femininity, once it is somehow explicitly there throughout his work, from Studies on Hysteria (1895[1893]/1996) to Analysis Terminable and Interminable (1937/1996).

In Freud's work, the question "what is a woman?" unfolds into another, one that does receive more attention from the author: "what does a woman want?". That doesn't mean that Freud offers many clues to his answer, although here that question seems to be included in the interests of Psychoanalysis. Freud (1918[1917]/1996) describes women as incomprehensible, mysterious, strange and hostile (taking the terms he uses to describe them in The Taboo of Virginity). In the same manner, the expression "dark continent" (1926/1996, p. 205) employed by Freud in the field that relates to women also evidences how great a question this was to him.

Considering the extent of the topic of femininity in Freud's work, a delineation is proposed concerning the relation that the author establishes between motherhood and femininity. As stated by Freud, femininity is one of the possible paths of the Oedipus Complex, reached when she becomes a mother.

Freud (1931/1996) indicates that, when it comes to a girl's oedipal experience, she acknowledges her castration and, consequently, the boy's superiority, an acknowledgement from which three possibilities derive: in the first path, the girl would stick to a general repulsion to sexuality; as a second possibility, she would hold on to her threatened masculinity in self-affirmation, that is, in the hopes of having a penis; and a third hypothesis is that she would follow a path that would lead her in the "normal" feminine attitude, taking her father as the object of love, which is later admitted as impossible and makes her turn to another man who can give her a child later in adult life. This latter possibility is described by Freud as the feminine form of the Oedipus Complex. 
On that note, the development of femininity must take place during the phase that is initiated by the Castration Complex. During this phase, the girl, disappointed in her mother (especially because she blames her for coming into this world "incomplete"), turns to her father, entering the Oedipus itself. André (2011) stresses that this phase begins with a passage: the mother is substituted by the father, and consequently, the desire for a child overtakes the desire for a penis.

In a way, the girl never renounces the penis. To Freud, she only searches for a substitute for it, an equivalent. In that sense, André (2011) accentuates that is is not about a metaphorical substitution but rather a metonymic one: the passage from penis to child, in the author's opinion, doesn't seem to produce a new signification.

Going back to the matter of jouissance, Julieta Jerusalinsky (2009) underlines that the passage from one term to another in this equation always produces, for the woman, an encounter with a jouissance not fully articulated as phallic. The woman does not occupy a position of conveyor of the phallus, which may have an effect of deprivation or frustration, but that may also enableaccessing an Other jouissance in order to create, supplementarily, when confronted by the lack.

André (2011) also indicates that the possibility for a child to constitute the sign for feminine identity related to the lack of the penis is always a hope (or a denegation). "(... ) the child teaches us that motherhood, in that viewpoint, is often followed by depression, or by an external joy, which is highly revealing", André remarks (2011, p. 212).

In consonance with the author, we resort to a few more clinical passages:

"He eats, shits and sleeps. Eats, shits and sleeps. And I, feeling nauseous, can't eat, can only take a shit in a hurry and, since he cries, I can't sleep. Oh yeah, he cries too... we are alike in that: we're always crying". (Patient E)

"If I gave him life, I should be able to keep deciding if it's worth it." (Patient B)

These passages denounce that motherhood isn't always experienced as a "narcissistic completeness", as is usually attributed to the maternal figure. They are images of that "external joy" as referred by André (2011). As a rule, they are statements said almost as confessions, as a consequence of how difficult it is to recognize that motherhood is also filled with hostility.

It may be thought that those are also images that describe the encounter/ separation of mother and woman. As will be debated further on, the feminine jouissanceis produced by thewoman's condition of being not-wholein castration, not-whole as referred to the phallic order. Such condition, given the not-whole 
relation with the phallus, makes women reveal a certain degree of "madness" which may produce disorder and horror or potency and creation.

\section{THE WOMAN AND THE MOTHER}

Freud indicates that the psychic inscription of the maternal body as a sexual one is the condition for the possibility of any representation of the feminine. Acknowledging maternal castration and, as a result, taking the mother as the a subject of desire, promotes a split, as Poli (2007) puts it: on one hand it is from that acknowledgement that the "representation" of the woman's sex derives, on the other hand, however, the maternal field always resists the operation of phallic signification.

The impossibility for a representation of the maternal sex is the core of the feminine enigma. The mother's body neverceases to be the body of incest. Lacan takes the unintelligible rest of this operation as something that arises from the own structure of language. In that manner, Lacan (1973[1972]/1985) says that the woman is not whole, that is, "there's always something about her that cannot be grasped by discourse" (p. 46).

Only when Lacan starts to work on the limits of the symbolic, with his formulations on the order of Real, does the matter of the feminine start to be emphasized as well. The point that touches the unnameable object of pulsion, Lacan names as "object a" those body pieces shared in one only mother-baby body - breast, feces, urine, lookand voice. Thoseobjects make up theerogenous borders of the body, being inapprehensible in their totality.

These matters are implied in Lacan's famous statement that "the woman does not exist". Miller (2010) remarks that saying that is not the same as saying that the woman's place does not exist. It does, but it remains empty, although that emptiness doesn't mean there's nothing there. According to the author, what we find in that place are masks, "masks of nothing" (p. 2).

The feminine in psychoanalysis regards the paradox of something impossible to be attained by knowledge, as something that is not comprised in the dialectics of representation, Miller (2010) points to that matter by stating that women have a special relation with the "nothing". That which has the function of veiling this nothing, Lacan calls "semblance". First, as pointed by Miller (2010), it's necessary to cover women (the veil of semblance) because The woman cannot be discovered: it's necessary to invent her, as exposed ahead.

According to Lacan (1973[1972]/1985), the inscription as man or woman, developed with the "quantic formulas of sexuation", indicates the division of every speaking being. In this sense, André (2011) considers that the formulas 
of sexuation are the result of the way Lacan reinterprets the Freudian notion of bisexuality.

Here also the "choice" of subjective position is determined within discourse itself and may not correspond to its anatomy. Both sides, man and woman, refer to one single function, the phallic function, beacon to the field of sexuality. That way, it is not phallic law in itself that makes them different, but the subjective position through which they declare to be subjected to it.

Any speaking being whatsoever, as is expressly formulated in Freudian theory, whether provided with the attributes of masculinity - attributes that remain to be determined - or not, is allowed to inscribe itself in this part (the woman part). If it inscribes itself there, it will not allow for any universality - it will be a notwhole, insofar as it has the choice of positing itself in $\Phi x$ or of not being there.

Those are the only possible definitions of the so-called man or woman portion for that which finds itself in the position of inhabiting language (LACAN, 1973[1972]/1985, p. 107).

In the formulas of sexuation, Lacan writes that none of them can escape castration, whereas, even unable to escape it, they are only partially subjected to it: it is "not-whole" in castration, "not-whole" articulated to the phallic order. Once the phallus has more of an effect of dividing than unifying the feminine position, in the field of phallic jouissance that happens as well. Thus, while part of it is stuck to the phallic jouissance, the other part lies in the Other's jouissance, in the jouissance of the body.

Lacan (1973[1972]/1985) indicates that the matter of jouissance is relative to a being determined as speaking (parletre). He also denotes that the needs of the speaking being are implied in an "other satisfaction", in a satisfaction sustained by language, a satisfaction that is not a need of the organism, but a need of the word. That other satisfaction is born out of the transmutation of the object of need into an object cause of desire, such as the one that the baby finds in the mother's breast, which satisfies much more than the need for satisfaction of hunger. In André's words (2011, p. 269): "speaking of jouissance means forcibly shifting jouissance in the word, surrender to a jouissance that consists of the very articulation of signifiers".

Amidst the satisfaction of needs, the jouissance of the word (phallic) and the jouissance of being (feminine), a lack is fundamentally imposed. This lack is inherent to the word, to the mechanism of the signifier, once the signification is always lacking regarding its reference. André (2011) underlines that such stratification lies in the core of the questioning concerning women. 
In Freud, the notion of lack is always linked to the psychic elaboration facing anatomical difference. To Lacan, castration is the point where the phallus, as a signifier, occurs as lacking, as failing. The phallus allows the subject to represent him or herself before that which has no representation in the unconscious: the sexual difference.

Hence, the mark of lack in the signifier phallus causes every subject to be marked by castration. In the woman, it is a double lack: to the lack that founds her as subject is added the one that founds her as woman, for there is no signifier that speaks of her sex.

That causes Miller (2010) to assert that one can only speak of a feminine clinic from the definition of "loss", "that fundamental loss with which the subject associates" (p. 4). Freud underlines a few supplements that the subject can invent for his "loss". One of them is the child, where motherhood is hereby understood as part of feminine psychopathology. Becoming a mother, in the Other of demand, is becoming one who "has". Miller highlights that Freud situates the feminine solution in the order of "having" and proposes, in accordance with Lacan, another solution, in the order of "being". That order implies not sealing shut the hole of lack but indeed fabricating a being with "nothing". This solution would hold a reduction of the being of the Other to a semblance.

The author reminds us that Lacan doesn't just say "The woman does not exist", he also says that "there are true women", where he concludes that there is a relation between woman and truth that depends on the semblance ${ }^{2}$, taking into account that truth and knowledge are different and that the truth has the structure of fiction. Regarding the question "what is a woman?", Miller (2010) states that Lacan points to a simple answer: in a woman, what is true is measured by her subjective distance in relation to her mother's position. The "true woman" can be told one by one and in very specific occasions, because it's not certain that someone can sustain the position of a true woman. "This is a true woman" can only be said in a yelp of surprise, may it be in wonder or horror, and perhaps only when it is realized that the mother visibly did not seal the hole in her", the author writes (p. 7).

To illustrate this true woman, Miller (2010) resorts to the same image that Lacan (1960[1959]/1988) offers: Euripides' Medea. In a few words, to recall the plot, Medea, wife of Jason, had done everything to please her man (betrayed her father, her country, etc.) and, because of that, lived in exile in Corinth, skillfully exercising her attributions as wife and mother. Until Jason announces that he is to marry another. As revenge, Medea murders her own children (as well as the new woman), all that was dearest to Jason.

Even though she was described as a woman who loves her children, Medea murders them with the irreducible intention of afflicting Jason. Miller (2010) 
points out that the woman in Medea overcomes the mother. An emblematic figure, Medea radicalizes what, with Lacan (1958/1998), may be understood as the act of a true woman: opening up in the man the hole that cannot be filled (a hole that she knows all to well), no matter the cost.

The true woman resorts to the "loss" as her most powerful weapon. With "loss", she articulates, exercises, acts. The true woman is the very contradiction and exemplarity of the famous adage that "less is more".

One must remember the important consideration that the "yelp of surprise" that inevitably echoes off the encounter with a "true woman" may be one of horror, as with Medea, but it may also be one of wonder, according to Miller (2010). Being "whole" in the phallic instance (man's side) organizes, in one way, but it also keeps in an alienated reference, in another way. Also in "counterparts", being "not-whole" in castration on one hand offers (Medea) conditions to promote horrors, but on the other hand makes room for the wonder of creation, of invention.

Perhaps it is not in vain that artists are often recognized as "feminine": art achieves potency on the woman's side. In the same way, it is important to question what consequence would result if the mother's position could also be thought on that side. That is what the inclusion of the "feminine jouissance" in motherhood rouses to interrogate.

\section{WHEN IT IS TIME TO CONCLUDE}

Lacan always drew attention to the mother's desire. As underlined by Soler (2013), there where the mother of love had appeared, he summoned the woman. Initially, the woman was the father's woman. Throughout his teachings, Lacan goes, however, beyond Oedipus, to the point of situating the barred woman, Other, not-wholly occupied with man or child.

For purposes of justice, both Freud and Lacan, in their manners and time, gave clues as to the consequences of the dissidence of the desire of the mother (or better, the woman when she is a mother). In contemporaneity, the objects incarnate that dissidence, that divide mother/woman, assume a wide array of possibilities, beyond the man.

The last hundred years have caused true revolution concerning the social place of women in western culture. As remarked by Nunes (2011), the political conquests of feminist movements have certainly been an important motor for those changes. Aside from those, it is important to mention the advent of birth control pills as another fundamental event that allowed unbinding sex from motherhood as well as the woman herself from the mother.

These and so many other milestones in history over the past century have made these questions much more frequent: if a woman wants to have children or 
not, when and how she can do it. When that starts to drift from a natural condition, the question of motherhood assumes contours of singularity, that is, each woman starts having to position herself in a very specific and standing manner as the array of "admitted" possibilities is widened culturally. And those are precisely the points that the clinical passages presented seem to demonstrate.

Lacan's considerations on the field of jouissance endorse those matters. Although phallic jouissance and feminine jouissance both operate on the field of singularity, further beyond the phallic reference, particular to the feminine jouissance, a question arises that calls out to the subject in a very specific way: calls out to the subject's madness, in the potency of horror and wonder.

"When a woman is a mother" reveals that those are terms that are not covered in psychoanalysis. That is exactly why it is possible to conceive an encounter between both positions (a sexed position with a determined function, maternal). If motherhood can bear something "beyond phallic jouissance", that indicates a path, a moment, when a woman is a mother, it is always up to psychoanalysis to interrogate about the consequences of such an encounter.

NOTES

1. It is not about establishing a group of enough "subjects" in number and criteria to surpass the conclusions that will be revealed, as is with a quantitative or even a qualitative research. It is, actually, about working with Psychoanalysis itself as a method and trying to explore some defined points among the discursive manifestations that a given time and culture are capable of producing and that are revealed, preeminently, in the space opened by the psychoanalytical clinic.

2. It is worth pointing out that Lacan vastly works on the matter of semblance in his seminars, especially in Seminar 18, D'un discours qui ne serait pas du semblant (1971/2009). At this moment, that reference is indicated inasmuch as broadening this discussion evades the objectives proposed by this article.

Recebido/Received: 10/5/2015. Aprovado/Accepted: 20/10/2015. 


\section{REFERENCES}

André, S. O Que Quer uma Mulher? Rio de Janeiro: Zahar, 2011.

Freud, S. (1895[1893]). Estudos sobre a Histeria. Rio de Janeiro: Imago, 1996, p. 13-316. (Edição Standard Brasileira das Obras Psicológicas Completas de Sigmund Freud. vol. 2).

(1905). Três Ensaios Sobre a Teoria da Sexualidade. Rio de Janeiro: Imago, 1996, p. 117-231. (ESB, 7)

. (1918[1917]). O Tabu da Virgindade - Contribuição à Psico-

logia do Amor III. Rio de Janeiro: Imago, 1996, p. 197-215. (ESB, 11)

1920. Além do Princípio do Prazer. Rio de Janeiro: Imago,

1996, p. 11-75. (ESB, 18)

1921. Psicologia das Massas e Análise do Eu. Rio de Janeiro:

Cia das Letras, 2001.

. 1923. A Organização Genital Infantil: Uma interpolação na teoria da sexualidade. Rio de Janeiro: Imago, 1996, p. 153-161. (ESB, 19) . 1926. A Questão da Análise Leiga. Rio de Janeiro: Imago, 1996,

p. 175-240. (ESB, 21)

. 1930[1929]. O Mal-Estar na Civilização. Rio de Janeiro: Imago, 1996, p. 67-148. (ESB, 20)

. 1931. Sexualidade Feminina. Rio de Janeiro: Imago, 1996, p.

229-251. (ESB, 21)

. 1933[1932]. Feminilidade. Novas Conferências Introdutórias

sobre Psicanálise. Rio de Janeiro: Imago, 1996, p. 113-134. (ESB, 22)

. 1937. Análise Terminável e Interminável. Rio de Janeiro: Imago, 1996, p. 225-274. (ESB, 23)

Harari, R. Por que não há relação sexual? Rio de Janeiro: Cia de Freud, 2006.

Jerusalinsky, J. A Criação da Criança: Letra e gozo nos primórdios do psiquismo. Tese

(Doutorado em Psicologia Clínica) - Programa de Pós-Graduação em Psicologia Clínica, Pontifícia Universidade Católica de São Paulo, São Paulo, 2009.

Lacan, J. O Seminário - Livro 7. A Ética da Psicanálise. Rio de Janeiro: Jorge Zahar, 1960[1959]/1988.

Juventude de Gide ou a letra e o desejo.. In: Escritos.

Campo Freudiano no Brasil. Rio de Janeiro: Jorge Zahar, 1958/1998, p. 739-775.

. Diretrizes para um Congresso sobre Sexualidade Feminina. In: . Escritos. Campo Freudiano no Brasil. Rio de Janeiro: Jorge Zahar, 1960/1998, p. 734-745. . O Seminário - Livro 18. De um discurso que não fosse semblante. Rio de Janeiro, Jorge Zahar, 1971/2009.

O Seminário - Livro 20. Mais, Ainda. 2a ed. Rio de Janeiro: Jorge Zahar, 1973[1972]/1985.

Miller, J. A. Mulheres e Semblantes II. Revista Opção Lacaniana. [Online]. Nova Série. Ano I, Número 1. 2010. Disponível em: http://www.opcaolacaniana.com.br/pdf/numero_1/Mulheres_e_semblantes_Il.pdf. Acesso em: 12 nov. 2012. 
Miranda, E. R. O Gozo no Feminino. Tese (Doutorado) - Universidade Estadual do Rio de Janeiro. Orientadora: Sônia Alberti, 2011.

Nunes, S. A. Afinal, o que querem as mulheres? Maternidade e Mal-Estar. Revista Psicologia Clínica. Rio de Janeiro, Volume 23, Número 02, 2011, p. 101-115.

Poli, M. C. Feminino/Masculino. Rio de Janeiro: Jorge Zahar, 2007.

Sigal, A. M.. A Psicanálise, o Feminino e sua Relação com as Novas Técnicas de Fertilização Assistida. Estados Gerais da Psicanálise: Segundo Encontro Mundial. Rio de Janeiro. 2003. Disponível em: http://egp. dreamhosters.com/encontros/mundial_rj/download/5b_Sigal_2 7260803_port.pdf. Acesso em: 12 mai. 2013.

Soler, C. O Que Lacan Dizia das Mulheres. Edição Digital, não paginada. Rio de Janeiro: Jorge Zahar, 2013.

Márcia Barcellos Alves

emarciaba@gmail.com

Maria Cristina Poli

mccpoli@gmail.com

Traduzido do português por Leonor Nunes Erberich/translated from portuguese by Leonor Nunes Erberich 
